Ethiopian Journal of Environmental Studies \& Management 9(4): 405 - 411, 2016.

ISSN:1998-0507

doi: http://dx.doi.org/10.4314/ejesm.v9i4.2

Submitted: November 20, 2015

Accepted: June 09, 2016

\title{
ASSESSING THE IMPACT OF SELECTED MACROECONOMIC VARIABLES IN THE DETERMINANTS OF SUSTAINABLE RESIDENTIAL HOUSING PRICES IN LAGOS
}

\author{
OLOWOFESO, E. ${ }^{1}$ AND *OYETUNJI, A.K. ${ }^{2}$ \\ ${ }^{1}$ Department of Entrepreneurship Management Technology, School of Management Technology, \\ Federal University of Technology, Akure, Nigeria \\ ${ }^{2}$ Department of Estate Management, Faculty of Environmental Sciences, University of Benin, \\ Benin City, Nigeria
}

\begin{abstract}
This paper examined the effects of some selected macroeconomic variables on residential property price in Lagos. Data were collected from Estate Surveyors and Valuers using the simple random sampling technique and Central Bank of Nigeria (CBN) Statistical Bulletin. The semi-log form of regression equation model was employed to determine the degree of relationship between the identified dependent and independent variables. Findings showed a positive impact of some independent variables in the determination of residential property price. This is evidenced by the interest rate possessing a t-value of $1.020,1.236$ and 1.512 while exchange rate with a t-value of $5.537,6.845$ and 8.822 denoting their influence as they are positively correlated towards the determinants of the prices of block of flats, detached house and duplex respectively. It was also revealed that fluctuation in the macroeconomic variables can lead to a corresponding change in the price of the residential property. It was recommended that financial institutions needs to reduce their lending rates to encourage investors.
\end{abstract}

Key Words: Macroeconomic variables, Housing price, Economic development, Determinants

\section{Introduction}

The impact of macroeconomic variables to the broad economy at the regional or national level cannot be over emphasised. Macroeconomic variables such as economic output, unemployment, inflation, savings and investment are key indicators of economic performance; therefore, they are closely monitored by governments, businesses and consumers (Khalid et al, 2012). According to Khalid et al. (2012), five common macroeconomic factors are the rate of inflation (affects prices for inputs and outputs in the short run and interest rates over the longer run in an economy), rates of interest (affects cost of capital which is the interest expenses hence property values), rate of unemployment (affects available income and hence disposable income for investments since this is an important source of internal equity capital), rate of growth in GDP (affects the domestic demand for national 
outputs), and rate of foreign exchange (affects the value of the currency relative to international currency hence affecting property values where different currencies are involved as well as the export demand for outputs) (Khalid et al. 2012).

In recent years, rapid economic development has resulted in an increasing demand for residential housing among urban areas in Nigeria. Reviewing the housing prices in Nigeria revealed that the prices have appreciated dramatically in some major cities and towns owing to increased quest for Nigerian to own homes coupled by an increased demand for residential homes due to increased rural urban migration, as well as demand for office space as more small and medium enterprises come into being (Nzalu, 2012). Wisniewski (2011) reported that the processes occurring in real estate are subject to different impulses depending on prevailing financial and economic situation of a given country.

Different macro-economic factors vary over time and they influence economic processes, practices and outputs in any economy. Lynn (2007) stated that since macro-economic factors often influence one another, and at times very correlated, when one factor changes, ripple effect occurs and the economy is affected much more. To this end, measuring the effect of macroeconomic variables is usually a difficult endeavor.

This paper examined the effect of some selected macroeconomic variables such as interest rates, GDP/income, inflation, exchange rate on residential property prices in Lagos, Nigeria. This study examined the effects as a factor influencing residential property prices in
Lagos, Nigeria. Lagos State was chosen for the study being one of the administrative, political, commercial and highly density cities of the country where demand of residential property is always on the increase. The study was concentrated on three categories of residential properties which are block of flats, detached houses and duplex. The study also adopted the used of annual data of some selected macroeconomic indicators like Interest Rate, Exchange Rate, Gross Domestic Product and Inflation Rate as an independent variables for the study. The data employed were obtained from the Central Bank of Nigeria $(\mathrm{CBN})$ statistical bulletin and it spans from 1989 to 2008.

\section{Literature Review}

Real estate industry has been undergoing drastic reforms due to the liberalization of financial markets, the unstable interest rates, the obsolescence of the existing stock of housing, and a change in consumer norms on housing uses. In addition, the housing sector has been a target of government fiscal and monetary policy aimed at achieving low inflation, low unemployment, and balanced growth. Existing literature shows that housing price movement area closely related to a common set of macroeconomic variables and market specific conditions. Zhu and Davis (2004), examine the determinants of housing prices in a number of industrialized economics, and noted that economic growth, inflation, interest rates, bank lending and equity prices have significant explanatory power.

Like any other sector of investment, real estate is affected by diverse factors including; fluctuations in exchange rate, 
interest rate, inflation rate, money supply, national output amongst others. O'Sullivan and Sheffrin (2003) indicated that an exchange rate between two currencies is the rate at which one currency will be exchanged for another. Olowofeso and Oyetunji (2013) opined that mortgage interest rate is an important variable that influences the decisions of individuals towards housing investment. When the mortgage rate increases, people are prevented from buying houses; therefore, the demand for housing decreases.

It has been argued that significant interest rate effects on consumer expenditure are expected through housing wealth, especially in systems characterized by the importance of the collateral role of houses (Muellbauer, 1992; Muellbauer and Murphy, 1997). In addition to money supply, other economic variables, such as employment and mortgage interest rates, can affect both housing prices and the construction of new housing (Olowofeso and Oyetunji, 2013).

\section{Research Methodology}

The use of primary and secondary data was employed for the study. Information on the prices of the properties within the study area was collected through the use of questionnaires while the selected macroeconomic variables were obtained from the Central Bank of Nigeria (CBN) Statistical Bulletin. The total of 276 practicing Estate Surveyors and Valuers in Lagos State as contained in the 2009 directory published by Nigerian Institutions of Estate Surveyors and Valuers (NIESV) constitutes the sample frame and population for the study. The Kothari (2004) formula was used to determine the sample size of the Estate Surveyors and Valuers in the study area. The Kothari formula adopted in the study is

$n=\frac{Z^{2} \cdot p \cdot q \cdot N}{e^{2}(N-1)}+Z^{2} \cdot p \cdot q$

Where, $n=$ sample size. $Z=$ value of the standard deviation at confidence level taken from table of normal curve as 1.96, $p=$ sample population taken as 50\% (0.05), $q=1-p$, i.e. $(1-0.05), N=$ size of population (276), $e=$ acceptable error taken at $2 \%$.

Substituting the variables, into the formula, the sample size for the study is given as 247 which represents $89.5 \%$ of the total population. These 247 Estate Surveyors and Valuers practicing in the study area were then randomly selected.

\section{Research Hypothesis}

In line with the objectives of study, the following null hypothesis is set:

$\mathrm{H}_{\mathrm{o}}$ : Change in macro-economic variables has no significant effect on residential property prices.

The macroeconomic and housing variables identified for the study is shown in Table 1. 
Table 1: Operationalization of variables

\begin{tabular}{lll}
\hline Variable code & Definition & Scale \\
\hline Dependent variable & Residential Property Prices & Naira \\
Independent variables & & \\
MIR & Mortgage interest rate & Naira/Percentage \\
EXR & Exchange rate & Naira/Percentage \\
GDP & Gross Domestic Product & Naira/Percentage \\
$I N F$ & Inflation rate & Naira/Percentage \\
\hline
\end{tabular}

\section{Model Specification}

The study adopts the semi-log form of regression equation which is given as:

$$
\begin{aligned}
& R P P=\beta_{O}+(M I R) \log \beta_{1}+(E X R) \log \beta_{2} \\
& +(G D P) \log \beta_{3}+(I N F) \log \beta_{4}+\ell i \ldots \ldots . .(\mathrm{ii})
\end{aligned}
$$

Where $\beta_{0}, \beta_{1}, \beta_{2}, \beta_{3,} \beta_{4}$ are parameters to be estimated, $\ell i=$ Error term

The functional form was used to determine that which best explained the dependent variable. It was also used to select the optimal number of independent variables (i.e. to isolate the irrelevant variable that were included in the function) which led to the model. The model was then evaluated on the basis of the magnitude of the coefficients of multiple determinants $\left(\mathrm{R}^{2}\right)$, the statistical significant of the coefficient based on the t-test, the significance of the overall equation as determined by the F-values, as well as the appropriateness of the signs of the regression coefficients. Regression analysis was used to analyze factors influencing the residential property prices in the study area. The results were also used to test the hypothesis formulated for the study.

\section{Result and Discussion}

Table 2: Regression Coefficient for Block of Flats

\begin{tabular}{llll}
\hline Variable & coefficient & $\mathrm{t}$-value & sig \\
\hline (Constant) & 4.427 & 20.932 & 0.000 \\
$\mathrm{x}_{1}$ & 0.010 & 1.020 & 0.324 \\
$\mathrm{x}_{2}$ & 0.000 & 5.537 & 0.000 \\
$\mathrm{x}_{3}$ & 0.002 & 0.174 & 0.864 \\
$\mathrm{x}_{4}$ & -0.000 & 0.587 & 0.566 \\
\hline
\end{tabular}

From Table 2, the independent variables interest rate $\left(\mathrm{x}_{1}\right)$, exchange rate $\left(\mathrm{x}_{2}\right)$ and gross domestic product $\left(\mathrm{x}_{3}\right)$ are positively correlated to the dependent variable. This shows that an increase in the presence of these variables will lead to increase in the price for block of flat in the study area. On the other hand, the negative sign of the independent variableinflation $\left(\mathrm{x}_{4}\right)$ in the regression equation indicates that the presence of a unit increase in the Inflation will have a reducing effect on the price of the property.

From the parameter coefficient shown above the equation for this category of property is as shows below:

$\mathrm{RPP}=\beta_{0}+\mathrm{x}_{1} \log \beta_{1}+\mathrm{x}_{2} \log \beta_{2}+\mathrm{x}_{3} \log \beta_{3}$ $+\mathrm{x}_{4} \log \beta_{4}+\ell i$

Hence the regression model is given as: $\mathrm{RPP}=4.427+\mathrm{x}_{1} \log 0.01+\mathrm{x}_{2} \log 0.000+$ $\mathrm{x}_{3} \log 0.002+\mathrm{x}_{4} \log -0.000$ 
Table 3: Regression Coefficient for Detached Houses

\begin{tabular}{llll}
\hline Variable & coefficient & t-value & sig \\
\hline (Constants) & 4.424 & 22.763 & 0.000 \\
$\mathrm{x}_{1}$ & 0.011 & 1.236 & 0.235 \\
$\mathrm{x}_{2}$ & 0.007 & 6.845 & 0.000 \\
$\mathrm{x}_{3}$ & 0.001 & 0.057 & 0.955 \\
$\mathrm{x}_{4}$ & 0.000 & -0.555 & 0.587 \\
\hline
\end{tabular}

Table 3 showed that all the independent variables interest rate $\left(\mathrm{x}_{1}\right)$ exchange rate, $\left(\mathrm{x}_{2}\right)$, gross domestic product $\left(\mathrm{x}_{3}\right)$ and inflation rate $\left(\mathrm{x}_{4}\right)$ have positive correction with dependent variable. This shows that a unit increase in each of these independent variables $\mathrm{x}_{1}$, $\mathrm{x}_{2}, \mathrm{x}_{3}$, and $\mathrm{x}_{4}$ will lead to an increase in the price of the property.

From these parameter above the equation for this type of property can be given as

$\mathrm{RPP}=\beta_{0}+\mathrm{x}_{1} \log \beta_{1}+\mathrm{x}_{2} \log \beta_{2}+\mathrm{x}_{3} \log \beta_{3}$ $+x_{4} \log \beta_{4}+\ell i \ldots \ldots \ldots \ldots \ldots \ldots \ldots$ (v)

Hence, the regression model also be given as

$\mathrm{RPP}=4.424+\mathrm{x}_{1} \log 0.011+\mathrm{x}_{2} \log 0.007$

$+\mathrm{x}_{3} \log 0.001+\mathrm{x}_{4} \log 0.000$

Table 4: Regression Coefficient for Duplex

\begin{tabular}{llll}
\hline Variable & coefficient & $\mathrm{t}$-value & $\mathrm{sig}$ \\
\hline (Constants) & 4.481 & 28.314 & 0.000 \\
$\mathrm{x}_{1}$ & 0.011 & 1.512 & 0.151 \\
$\mathrm{x}_{2}$ & 0.008 & 8.822 & 0.000 \\
$\mathrm{x}_{3}$ & -0.003 & -0.350 & 0.731 \\
$\mathrm{x}_{4}$ & -0.002 & -1.140 & 0.272 \\
\hline
\end{tabular}

From the Table 4, two of the independent variables - interest rate $\left(\mathrm{x}_{1}\right)$ and exchange rate $\left(\mathrm{x}_{2}\right)$, are positively correlated with the dependent variable. This shows that any increase in these variables will lead to an increase in the housing price vis-à-vis. It is worthy to note that two other variables- gross domestic product $\left(\mathrm{x}_{3}\right)$ and inflation rate $\mathrm{x}_{4}$ are negatively correlated with dependent variable. This shows that a unit increase in these two independent variables $\mathrm{x}_{3}$ and $\mathrm{x}_{4}$ will lead to the corresponding decrease in the prices of the residential property. Thus the equation for the model is given as $\mathrm{RPP}=\beta_{0}+\mathrm{x}_{1} \log \beta_{1}+\mathrm{x}_{2} \log \beta_{2}+\mathrm{x}_{3} \log \beta_{3}$ $+x_{4} \log \beta_{4}+\ell i$.

Hence, the regression model is given as

$\mathrm{RPP}=4.481+\mathrm{x}_{1} \log 0.011+\mathrm{x}_{2} \log 0.008$ $-\mathrm{x}_{3} \log 0.003+\mathrm{x}_{4} \log -0.002 \ldots$ (viii)

\section{Test of Hypothesis}

The result for the block of flats as shown in Table 5 gives $R^{2}$ of 0.830 which is an indication that $83 \%$ of block of flats in the study area is attributed to the independent variable used for the assessment while the F-statistic of 18.325 falls within the region of rejection which is an indication that one of the coefficients in this model is non-zero. For detached houses, the result shows a high linear relationship between the dependent variable and the independent variables. The proportion of the relationship amongst the variables is given by $R^{2}=$ 0.879 connoting that $88 \%$ of variance in the dependent variable is attributable to the independent variables. The $F$-statistic of 27.280 falls in rejection region of the statistics. The performance of the equation for duplex is indicated by $R^{2}$ of 0.906 and F-statistic (46.997). The Rsquare (0.926) is the proportion of the variation in the dependent variable explained by the regression model. This is an indication that almost $93 \%$ of duplex in Lagos Nigeria is attributable to the independent variables used for the assessment. The F-statistic of 46.997 using analysis of variance falls within the region of rejection. The overall model is significant at 0.000 levels. 
Table 5: Analysis of variance for dependent variables

\begin{tabular}{llllll}
\hline Variables & $\mathrm{R}^{2}$ & Adj R $^{2}$ & F- statistic & Std. Error & Sig level \\
\hline Block of flats & 0.830 & 0.785 & 18.325 & 0.12924 & 0.000 \\
Detached houses & 0.879 & 0.847 & 27.280 & 0.11876 & 0.000 \\
Duplex & 0.926 & 0.906 & 46997 & 0.09671 & 0.000 \\
\hline
\end{tabular}

From the Analysis of variance (ANOVA) in table 5, above, it was discovered that F-statistics of the equation for all the properties are higher than 0.05 and thus falls within the region of rejection of the statistics. Also, the overall models for the properties are also significant at 0.000 level. Hence, the rejection of the null hypothesis which says that:

change in macro-economic variables has no significance effect on residential property prices. The degree of relationship between dependent and all the independent variables were examined and the proportion of the relationship amongst the variables as given by $R^{2}=$ $0.830,0.879$ and 0.926 for the block of flats, detached houses and duplex respectively. This means that the high percentage of variance in the residential property price in Lagos State is attributable to the independent variables. Another discovery was that result of the regression model shows a positive impact of some of the independent variables in the determinants of residential property price in the study area. The variables (interest rate and exchange rate) have positive impact with the dependent variable for all the class of properties examined while GDP and inflation rate does not. This shows that a unit increase in the presence of this independent variable will lead to an increase in the price of properties in the study area.

The findings of this study corroborates that of Ogonna Nneji (2013) and Ong (2013) which revealed that inflation rate is not a significant determinant of housing price as inflation does have an effect on the growth of house prices in the boom and steady-state regimes; while it negates that of Rosli (2013) which revealed that GDP is the strongest determinant of housing price. This study showed that not all housing units can the GDP be positively correlated in the determination of housing price since a negative correlation towards the determination of the prices of duplex in the study area is obtained.

\section{Conclusion and Policy Implications}

This study has established that fluctuation in macroeconomic variables lead to corresponding change in the price of the residential property. Therefore, there is need for the financial institutions to reduce their lending rates to avoidable rate and other macroeconomic variables such as exchange rate, gross domestic product and inflation rate should be made stable in the economy. Having established the fact that macroeconomic indicators has effect on the price of property using regression model, there is a need for Nigerian Estate Surveyors and Valuers to acquaint themselves with the use of the model where macroeconomic as a variables are incorporated to arrive at a concise property price rather than using the nature and the characteristics surrounding the property as a determinant factor for influencing property price. 


\section{References}

Khalid, Z., Iqtidar, A.S., Muhammad, M., K. and Mehboob, A. (2012). "Macroeconomic Factors Determining FDI Impact on Pakistan's Growth". South Asian Journal of Global Business Research, 1(1): $79-95$.

Kothari, C.R. (2004). Research Methodology: Methods and Techniques, New age International (p) Ltd, New Delhi.

Lynn, D.J. (2007) The Tectonic Forces of Global Real Estate: Implication for Global Investment and Portfolio Managers. Journal of Real Estate Portfolio Management, 13(1): 8792.

Muellbauer, J. (1992). Anglo-German Differences in Housing Market Dynamics: The Role of Institutions and Macroeconomic Policy. European Economic Review, Papers and Proceedings, 36: 539548.

Muellbauer, J. and Murphy, A. (1997). Booms and busts in the UK housing market. The Economic Journal, 107, 1701-1727.

Nzalu, F.M. (2012). An Assessment of the Factors Affecting the Growth in Real Estate Investment in Kenya. Unpublished MBA Project, University of Nairobi.

Ogonna Nneji, C.B. (2013). House Price Dynamics and Their Reaction to Macroeconomic Changes.
Olowofeso, E and Oyetunji, A.K (2013). Interest Rate as a Determinant of Housing Prices in Lagos State, Nigeria. International Journal of Economic Development Research and Investment, 4(3): 1 - 10.

Ong, T.S. (2013). Factors Affecting the Price of Housing in Malaysia. Journal of Emerging Issues in Economics, Finance and Banking. (JEIEFB). An Online Journal (ISSN:2306367X) Volume: 1 No.5

O'Sullivan, A. and Sheffrin, S.M. (2003). Economics: Principles in Action. Upper Saddle River, N. J.: Pearson Prentice Hall.

Rosli, S.B. (2013). The Effects of Macroeconomic Variables toward Housing Prices in Malaysia. Unpublished thesis for Bachelor of Business Administration (Hons) Finance, Faculty of Business Management, Universiti Teknologi Mara, Johor

Wisniewski, R. (2011). Modeling of Residential Property Prices Index using Committees of Artificial Neural Networks for PIGS. The European-G8, and Poland. Economic Modelling.

Zhu, H. and Davis, E.P. (2004). Bank Lending and Commercial Property Cycles. Some Country Evidence $\mathrm{B} / \mathrm{S}$ working papers no 150 . 